\title{
Thesis Guidance Effectiveness in University Setting
}

\author{
Rachmad Indra Widiantoro, MV. Roesminingsih, Ulil Hartono \\ Department of Educational Management \\ Universitas Negeri Surabaya \\ Surabaya, Indonesia \\ rachmad.indra.widianto@gmail.com
}

\begin{abstract}
This study aims to: (1) know the process of guiding the thesis preparation; (2) identify constraints that can hinder the effectiveness of the thesis preparation guidance, and (3) provide recommendations to overcome the constraints of the thesis preparation guidance in the Unesa Postgraduate Education Management Study Program. This type of research is exposfacto research. The subject of this study was the Head of Study Program, supervisor and students who took the thesis subject in the Education Management Master Program at Unesa Postgraduate Program. The technique of collecting data is interview, observation and documentation. Data analysis in this study with data reduction, data presentation and conclusion. The results of the study are (1) thesis guidance begins with the submission of titles, division of supervisors, implementation of guiding proposals, comprehensive sessions, thesis guidance, and thesis sessions. (2) the obstacle experienced is that students rarely do guidance, high flying hours of lecturers, and difficulty monitoring the progress of the thesis. (3) Efforts are made to improve student activity, improve monitoring of thesis work, manage the work of the thesis as well as possible, and make discussion groups.
\end{abstract}

Keywords-thesis guidance management; thesis guidance evaluation

\section{INTRODUCTION}

In the 21 st century there are various complex challenges and problems. These challenges occur in all aspects of human life, starting from social, economic, cultural, educational and other aspects of life. According to Kovacevic \& Pavlovic describe this century as cognitive capitalism; postindustrial society, neoliberal society, the information society, entrepreneurial society, postcapitalist society, risk society, and boring society [1].

In facing such complex challenges, the abilities and skills needed are very different from the previous period. From a study of various results of the study, Flynn identified there are six abilities needed to enter the life of the 21 st century, namely: the ability to process information, work together in a team, communicate skills, adapt / flexible, ICT, problem solving / thinking critical, and innovation. In another study [2]. Husin et al found that there were four abilities, namely: digital age literacy, Inventive thinking, Effective communication and High productivity. In the Malaysian context he added one more ability, namely: spiritual. Meanwhile, Twenty first century learning outcomes require self-knowledge: the internal capacity to define one's belief system, identity, and relationships [3].
In the higher education curriculum, research has a very strategic role in developing the ability to deal with the $21 \mathrm{st}$ century. Some studies show that student involvement in carrying out research can develop academic and social skills. Student research has several benefits such as analytic abilities, synthetic thinking, increasing trust in the ability to make presentations and speaking in forums [4]. Students involved in research projects gained practical skills to conduct research and important resources in their fields of study, critical thinking skills, logical thinking, and ability to synthesize information. In the social field, that student research projects can improve thinking skills, concept integration, independent learning and find information needed to complete tasks [4].

Given the great benefits of scientific research, the Indonesian government has long issued policies on final assignments, theses, theses and dissertations in the higher education curriculum. The latest policy was outlined in National Standards for Higher Education, which explains that: "able to assess the implications of the development or implementation of technological science that pays attention to and applies the values of humanities in accordance with their expertise based on scientific rules, procedures and ethics in order to produce solutions, ideas, designs or art criticism, compiling a scientific description of the results of the study in the form of a thesis or final assignment report, and uploading it on the college page; " At the level of student scientific research is a matter that must be done by students as one of the graduation requirements. Either at the Strata 1 level, which is called a thesis, the level of Strata 2 is called a thesis and at the level of Strata 3 is called a dissertation. For master program students, to maintain the quality of thesis research students do not walk alone but are guided by a lecturer called a supervisor [5]. Thus, it is expected that research conducted by students can run well and on time and will produce quality scientific work. However, in its implementation, it is not uncommon for students to encounter many obstacles and obstacles in completing their thesis, not a few students who finally add to the college period just to complete the graduation requirements in the form of thesis scientific work earlier. Some even ended up dropping out (DO) from campus because they were unable to complete the thesis because of various things. So that effective thesis guidance is needed so that the above problems can be minimized [6].

Effective thesis guidance can have a high quality of output (thesis product) in terms of content and order. Reality in the field shows that the process of thesis guidance or final assignment in Higher Education is still not optimal both in 
terms of quality and quantity of guidance. On the one hand students are required to diligently conduct thesis guidance with Supervisors, while on the other hand many Supervisors are busy. This is one of the obstacles in completing the thesis for students. Effectiveness is often referred to as doing the right thing, namely, carrying out activities that directly help the organization achieve its objectives [7].

Based on the results of self-evaluation of the Master of Education Management Study Program at Unesa Postgraduate, it is known that the number of students completing the thesis work on time (6 months) is $80 \%$ while $20 \%$ of students still need additional time to complete their thesis. This is considered not optimal, considering that the curriculum is designed so that all students can graduate within 4 semesters. This is thought to be caused by the presence of obstacles / difficulties for students in designing thesis research, understanding the right research methodology, and mastering the correct scientific writing techniques for the preparation of the thesis. Barriers to thesis preparation are thought to originate internally from students themselves and externally from guidance services, supporting facilities (availability of references both from print media / reference books, journals, research results or from electronic media / internet), sufficiency of supporting material for thesis supporting, etc.

Thus, the focuses of this study are, first, knowing the guidance process for preparing the thesis of students in the Education Management Master Program at Unesa Postgraduate. Second, identifying constraints that can hinder the effectiveness of the guidance of students' thesis preparation in the Education Management Master Program at Unesa Postgraduate. Third, providing recommendations on what efforts can be made by the Education Management Master Program in Unesa to overcome obstacles in the thesis preparation guidance.

\section{METHOD}

The focus of this study was to find out the implementation of thesis guidance in the Education Management Masters Program at Unesa Postgraduate. This study uses an expostfacto qualitative approach which is an empirical finding that is carried out systematically, researchers do not control the independent variables because their manifestations have already taken place or they cannot be manipulated inherently [7]. The technique of collecting data through interview techniques was carried out to several informants, namely Head of Study Program, Supervising Lecturer and Student of Education Management Masters Program, Unesa who took a thesis guidance program. Data collection techniques are carried out by observation and documentation in the field.

The design of this study is broadly divided into several stages, namely: (a) the preparation stage which contains the collection of data or information in accordance with the focus of the research problem in this study; (b) the implementation stage in the form of a study of the application of existing theories by conducting observations, surveys, and data collection in the field; (c) the final stage which contains data analysis, draw conclusions and compile research reports.
Qualitative research focuses on the description of data in the form of sentences that have profound meanings derived from informants and behaviors observed. The data from this research are in the form of facts found at the time in the field. In detail the design of this study begins with observations and brief interviews with the Head Department of Education Management in Unesa Postgraduate in the efforts of researchers to understand the conditions in the field which are used as background research and the selection and use of informants as pre-research activities. Furthermore, the stage of preparing equipment or materials for research purposes, namely by preparing various kinds of relevant questions related to the effectiveness of thesis guidance. The next step is to request permission to conduct research to the head of the Unesa Postgraduate Education Management Masters program and related parties that support the ongoing research. After the above process is complete, researchers need to prepare themselves to collect relevant data according to the research objectives and pay attention to ethics before going to do an interview. From the data that has been collected, the data analysis process is carried out, to strengthen the analysis the researcher compares the data obtained from the field with the relevant theory. The end of the research process is drawing conclusions and preparing a complete research report for further testing. In this study researchers prepared a design scheme as follows.

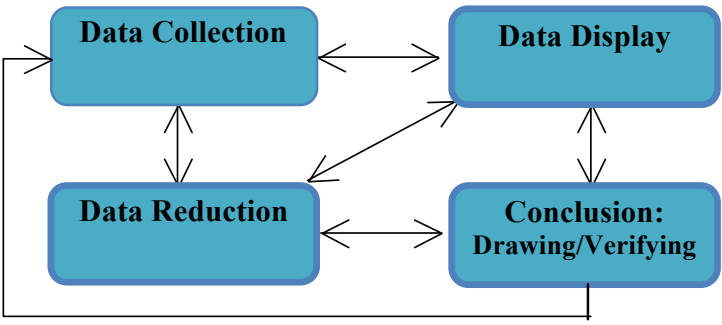

Fig. 1 Research Design

\section{RESULTS AND DISCUSSION}

The results of the research on Management of Thesis Guidance at the University Postgraduate Program are focused on 3 research focuses, namely, the implementation of the thesis guidance process, obstacles that occur when the technical guidance and efforts to improve the implementation of thesis guidance will be explained in the following discussion.

\section{A. Implementation of The Guidance Process for Preparing The Thesis of Students of the Education Management Masters Program at Unesa Postgraduate.}

Based on the interviews conducted by the author to the Head of Department, the thesis guidance begins with submitting 3 alternative thesis titles by students to the Head of Study Program in semester 3, then I and II Supervisors will determine the qualifications according to the title submitted by the students. Academically, the thesis course is in the fourth semester, but in the Education Management Study Program Master Program after obtaining the Advisory Lecture, students are expected to immediately contact their Supervisor to do thesis guidance. in semester 4 and the thesis can be completed quickly. After conducting guidance from chapter I to chapter 
III and obtaining approval from the First and Second Supervisors to conduct a Comprehensive Seminar because the research design was considered almost perfect, students would submit a comprehensive seminar to the Head of Department for further examinations of 2 lecturers and determined by the time to conduct a comprehensive seminar. After conducting a comprehensive seminar students will make improvements according to the examiners' input and to monitor the extent of improvement that students have made so that the students must meet with the examiners to show the results of improvements made, after all repairs are checked by examiners, students can submit comprehensive papers. to the post library then obtain proof of receipt from the library which will be used as a condition to submit a thesis session. After that students can do the next process to complete chapters IV and V in consultation with their supervisor. If chapters IV and $\mathrm{V}$ are considered ready to be tested, the students make another submission to the Head of Department for conducting the Thesis Session whose process is almost the same as the submission and implementation of the comprehensive seminar above. After correcting the chapters I to IV properly, students will get a validation signature from the Examining Lecturers, the Head of the Department and the Director of Postgraduate and the results of the thesis will be collected in the Pascasrajana Library.

B. Constraints that Can Hinder The Effectiveness of Guidance in The Preparation of Students' Thesis in The Education Management Masters Program at Unesa Postgraduate Program

Based on interviews conducted by the author found several obstacles in the implementation of thesis guidance. According to the Head of Department of Magister Education Management the obstacle of the smoothness of thesis guidance is when students experience difficulties in working on the thesis of the intensity of decreased guidance so that the supervisor is difficult to assist students in overcoming these difficulties. supervisor so difficult to find, and the difficulty of study program in monitoring the progress of guidance so that when there are problems or kemoloran in the guidance of the Head of Department can not give further action quickly and precisely. According to interviews with several thesis supervisors in the Magister Education Management Study Program, the obstacles that often occur in the nature of thesis counseling are students who do not conduct regular guidance, it is difficult to monitor the development of guidance students because 1 lecturer guides more than 1 student and there are some students who it is difficult to understand the direction of the supervisor. Whereas according to interviews with several Masters of Education Management students who took thesis courses stated that the obstacle of thesis guidance was the difficulty in managing guidance time because of the busy work of students, it was difficult to meet the supervisor because they had to adjust the time of student guidance and activity.

From interviews with the three informants above we can draw the conclusion that the constraints of thesis guidance are (1) It is rare for students to meet with supervisors for various reasons, some are lazy, busy or afraid to meet with the supervisor because the thesis is considered imperfect, (2) busyness between students and lecturers the supervisor so it is difficult to set the guidance time because some of the
Education Management Masters students have worked and the lecturers' flight hours are high, and (3) the difficulty of the supervisors to monitor the guidance students because of the many students being guided, because lecturers also guide across study programs. From some of the obstacles above kebanan comes from the student's own internal motivation, that intrinsic motivation is the desire to act due to motivating factors from within (internal) individuals [8].

\section{What efforts can be made by the Education Management Masters Program in Unesa to overcome obstacles in the preparation of thesis guidance.}

From the results of the interview, there were several efforts that could be done to overcome the obstacle of thesis guidance in the Education Management Study Program at Unesa Postgraduate Program. According to the Head of Department of Education Management efforts that can be done is to prepare students as early as possible through optimizing the proposal seminar subjects so that when taking thesis courses do not start from scratch for the work of the thesis, making deadlines / timelines from students supervised by supervisors and study programs to complete several the stages of the existing thesis, optimizing the monitoring of student thesis work so that when the progress of the student thesis which is considered late can be immediately detected and can be immediately given special treatment for the student, increasing the role of supervisor in providing guidance and motivation so that the thesis can be completed soon. According to some supervisors who the authors interviewed the efforts that could be made were to increase student activeness in conducting thesis guidance so that guidance could run smoothly and no students were missed in monitoring guidance, providing more time to provide guidance and directing students to guide them to complete the stages -The stages of the thesis work properly, correctly and quickly. According to students who take the thesis course of effort that students can do is to form a discussion group or group for the same supervisor so that they can provide information and motivation to conduct routine thesis guidance and to provide input if they encounter obstacles in conducting the thesis [9].

From interviews with the three informants above, generally the efforts that can be done are by (1) increasing motivation and active role of students in conducting thesis guidance so that students can have the desire and the willingness to be the best, this is in accordance with Mc's achievement motivation theory. Someone is considered to have motivation if he has the desire to perform better than others, (2) actively monitors the progress of the student thesis so that when there is a delay in work it can be detected immediately and given special treatment, this is in line that supervision is a process of observation of the implementation of the entire organization to ensure that all work being carried out goes according to a predetermined plan [1]. (3) students prepare as early and as detailed as possible the thesis that will be made through the proposal seminar course and manage the thesis work time well, it is in line with the time management theory that time management is a way of making time become controlled so as to guarantee the creation of an effectiveness and efficiency as well as productivity [10]. It is expected that good time management can increase the productivity of student thesis work both in quality, quality and 
work efficiency [6], and (4) create discussion groups or student work thesis guidance groups to motivate each other and exchange suggestions to be able to complete the thesis done by each student. This is in line with the theories understanding of group work as an activity of a group of students who are usually small in number, organized for learning purposes [4].

\section{CONCLUSION}

First, The implementation of the thesis begins with the process (a) submission of titles by students and then submitted to the study program to be determined 1 and 2 supervisors in accordance with the competency of the title proposed, (b) the implementation of thesis guidance begins with students meeting the supervisor for consultation title and carry out consultation of completion of thesis to supervisors 1 and 2, (c) if the thesis design of chapter $i$ to chapter iii is deemed feasible to be tested by the first and second supervisors, the student submits a comprehensive session to the lecturer to determine the implementation time and the examiner lecturer, if in the trial there were several revisions, students were required to make improvements to that section, (d) after comprehensive paper revisions were fulfilled, students could continue guidance for completing chapters iv and so on until they were feasible to be tested, for the process of submitting the process and the same form as when a comprehensive paper.

Second, Obstacles to thesis guidance at Unesa Postgraduate Education Management Study Program are (a) It is rare for students to meet with supervisors for various reasons, some are lazy, busy and afraid to meet the supervisor because the thesis is considered imperfect, (b) student activity with a supervisor so it is difficult to set the guidance time because some of the Education Management Masters students have worked and lecturers' flight hours are high, and (c) the difficulty of the supervisor to monitor guidance students because there are many students being guided, because lecturers also guide across study programs .

Third, Efforts that can be made to improve the effectiveness of thesis guidance in the Education Management Study Program at Unesa Postgraduate Program are by (a) increasing student motivation and active role in conducting thesis guidance so that students can have the desire and willingness to be the best, (b) monitor active progress of student thesis work so that when there is a delay in workmanship it can be immediately detected and given special treatment, (c) students prepare as early and as detailed as possible the thesis will be made through the proposal seminar course and manage the thesis execution time well, and (d) create a discussion group or student thesis group work to motivate each other and exchange suggestions to be able to complete the thesis done by each student [11]

The following are suggestions that the researcher can give so that the thesis guidance in the Management Master of Education in Unesa Postgraduate can be more effective. (a) The effectiveness of the thesis guidance in the Education Management Master's Degree Program in Unesa needs to be improved so that in the future the graduation rate on time can reach $100 \%$ per year. (b) The Master of Education Management Study Program Unesa's postgraduate program needs to improve thesis guidance services through monitoring the progress of more intensive student guidance so that it can scan any delay in completing a student's thesis from the specified time (6 months).

\section{REFERENCES}

[1] D. Dobni and G. M. Zinkhan, "In search of brand image: A foundation analysis," ACR North Am. Adv., 1990.

[2] T. T. Flynn, "Do they have what it takes: A review of the literature on knowledge, competencies and skills necessary for 21 st century public relations practitioners in Canada," Can. J. Commun., vol. 39, no. 3, 2014.

[3] W. N. F. W. Husin et al., "Fostering students' 21st century skills through Project Oriented Problem Based Learning (POPBL) in integrated STEM education program," in Asia-Pacific Forum on Science Learning and Teaching, 2016, vol. 17, no. 1, pp. 1-18.

[4] J. Ishiyama, "Does early participation in undergraduate research benefit social science and humanities students?," Coll. Stud. J., vol. 36, no. 3, pp. 381-387, 2002

[5] K. L. Webber, T. F. N. Laird, and A. M. BrckaLorenz, "Student and faculty member engagement in undergraduate research," Res. High. Educ., vol. 54, no. 2, pp. 227-249, 2013.

[6] M. B. Baxter Magolda, "Self- authorship: The foundation for twenty- first- century education," New Dir. Teach. Learn., vol. 2007, no. 109 , pp. 69-83, 2007

[7] M. B. Miles and A. M. Huberman, "Qualitative data analysis: A sourcebook of new methods," in Qualitative data analysis: a sourcebook of new methods, Sage publications, 1984

[8] D. C. McClelland, Human motivation. CUP Archive, 1987.

[9] M. B. Triyono, "Pengaruh Strategi Pembelajaran Dan Kemampuan Analitik Terhadap Keterampilan Pneumatik Mahasiswa Teknik Mesin UNY,"J. Penelit. dan Eval. Pendidik., vol. 11, no. 1, 2008.

[10] J. Thomas, "Instructional Motivations: What Can We Learn from Homeschooling Families?," Qual. Rep., vol. 21, no. 11, pp. 2073-2086, 2016.

[11] A. W. Astin, "Student involvement: A developmental theory for higher education," J. Coll. student Pers., vol. 25, no. 4, pp. 297-308, 1984. 